\title{
The VEGF Pathway in Cancer and Disease: Responses, Resistance, and the Path Forward
}

\author{
Mark W. Kieran ${ }^{1,2}$, Raghu Kalluri ${ }^{3}$, and Yoon-Jae $\mathrm{Cho}^{4}$ \\ ${ }^{1}$ Department of Pediatric Medical Neuro-Oncology, Dana-Farber Cancer Institute, Boston, \\ Massachusetts 02115 \\ ${ }^{2}$ Division of Pediatric Oncology, Children's Hospital Boston, Boston, Massachusetts 02115 \\ ${ }^{3}$ Department of Biological Chemistry and Molecular Pharmacology, Beth Israel Deaconess Medical Center, \\ Boston, Massachusetts 02115 \\ ${ }^{4}$ Department of Neurology and Neurosurgery, Stanford University and Lucile Packard Children's Hospital, \\ Stanford, California 94305 \\ Correspondence: mark_kieran@dfci.harvard.edu
}

\begin{abstract}
Antiangiogenesis was proposed as a novel target for the treatment of cancer 40 years ago. Since the original hypothesis put forward by Judah Folkman in 1971, factors that mediate angiogenesis, their cellular targets, many of the pathways they signal, and inhibitors of the cytokines and receptors have been identified. Vascular endothelial growth factor (VEGF) is the most prominent among the angiogenic cytokines and is believed to play a central role in the process of neovascularization, both in cancer as well as other inflammatory diseases. This article reviews the biology of VEGF and its receptors, the use of anti-VEGF approaches in clinical disease, the toxicity of these therapies, and the resistance mechanisms that have limited the activity of these agents when used as monotherapy.
\end{abstract}

\begin{abstract}
$A^{\text {ngiogenesis is a vital physiologic process }}$ Aneeded for growth and development as well as wound healing and the menstrual cycle (Dvorak 2005; Bhadada et al. 2010). A major regulator of angiogenesis is vascular endothelial growth factor (VEGF) and its cognate receptor vascular endothelial growth factor receptor-2 (VEGFR2). Activation of the VEGF pathway has been identified in a large number of disease processes ranging from cancer to autoimmunity, retinopathy, and many more, which has led to the common perception that inhibition of the pathway would result in rapid and sustained clinical responses. As we have experienced
\end{abstract}

in the past, optimism of our success was overstated while the underlying biologic mechanisms that diseases can use to adapt to inhibition of the VEGF pathway were underestimated. There are real but isolated examples of success with VEGF inhibitors but also a great deal of clinical disappointment. This article reviews some of our understanding of the VEGF pathway and the inhibitors developed to target it. We then review results from a series of preclinical and clinical trials examining the activity of both VEGF and VEGFR2 inhibitors, examining the potential reason for both areas of success and failure. Finally, we

Editors: Michael Klagsbrun and Patricia D'Amore

Additional Perspectives on Angiogenesis available at www.perspectivesinmedicine.org

Copyright (C) 2012 Cold Spring Harbor Laboratory Press; all rights reserved; doi: 10.1101/cshperspect.a006593

Cite this article as Cold Spring Harb Perspect Med 2012;2:a006593 
M.W. Kieran et al.

briefly discuss some of the future directions aimed to build on our successes while overcoming our failures.

\section{ANGIOGENESIS}

Our understanding of the biology that regulates angiogenesis has improved dramatically over the last 40 years. Initially thought to be the induction of a cytokine that induces endothelial cell proliferation and new blood vessel development, we now have a more detailed understanding of vasculogenesis (the formation of de novo endothelial cell precursors needed to initiate neovascularization) and angiogenesis (the stimulation of neovascularizaton from existing vessels) (Semenza 2007; Kassmeyer et al. 2009; Ribatti et al. 2009). Although this is not completely accurate, we will use "angiogenesis" and "antiangiogenesis" to refer to the process of neovascularization and its inhibition, even if the target is directed more toward vasculogenesis. Although lymphangiogenesis is another critical component of neovascularization and uses many of the same factors such as VEGF (which will also be targeted by VEGF inhibition), this process will be lumped into the general concept of "angiogenesis" (Lohela et al. 2009). The critical role of components other than endothelial cells, such as pericytes and matrix, have added another important layer onto our fundamental understanding of this process (Diaz-Flores et al. 2009). These provide us with opportunities to identify additional pathways to inhibit, but also provides tumors with additional potential escape mechanisms. The complexity of the neovascular process has become better delineated with the discovery of dozens of (rather than one) proangiogenic cytokines (e.g., basic fibroblast growth factor, PDGF, IL-8) and their cognate receptors (e.g., fibroblast growth factor receptor-1) that can stimulate angiogenesis (Murakami and Simons 2008; Cao 2009; De Val and Black 2009). Furthermore, multiple endogenous inhibitors of angiogenesis, such as endostatin, angiostatin, tumstatin, and thrombospondin have been identified that play an equally important role in regulating the angiogenic cascade (O'Reilly et al. 1994, 1997; Maeshima et al. 2000; Lawler and Detmar 2004; Maione et al. 2009; Ribatti 2009). Thus, angiogenesis is a complex interaction of many cell types, soluble stimulators, and inhibitors as well as the local matrix, inflammatory and immune cells, and bone marrow precursors, as well as the tumor, all acting in concert to determine the type, location, and abundance of the angiogenic response (Sozzani et al. 2007; Ahn and Brown 2009; Ramjaun and Hodivala-Dilke 2009). Because angiogenesis is an important adaptive response to the menstrual cycle, wound healing, cardiac ischemia, and many other physiologic processes, consideration of the consequences of inhibiting the VEGF pathway will need to be further studied (Yla-Herttuala et al. 2007).

\section{THE VEGF PATHWAY}

The concept that angiogenesis was an important and necessary aspect of disease and could therefore be used as a therapeutic strategy was first proposed by Judah Folkman in 1971 (Folkman 1971), 12 years before vascular permeability factor (VPF) was isolated (Senger et al. 1983) and 18 years before VEGF was sequenced (Ferrara and Henzel 1989). Interestingly, the sequence of VEGF was identical to that of vascular permeability factor or VPF, a finding that brought together important functions of this single molecule: endothelial proliferation and fluid leakage resulting in edema. Since its identification, other isoforms of VEGF and their receptors have been discovered (Roskoski 2008). Furthermore, alternative splice variants of VEGF have been identified including $\mathrm{VEGF}_{121}, \mathrm{VEGF}_{165}, \mathrm{VEGF}_{189}$, and $\mathrm{VEGF}_{206}$, each with a different primary role (Ferrara et al. 2003). For example, VEGF ${ }_{189}$ is the fulllength protein, forms a homodimer, and with $\mathrm{VEGF}_{206}$ has limited biologic activity because of their membrane localization as a result of heparin-binding sites, something that can be altered by proteolytic cleavage of a fragment of the protein. $\mathrm{VEGF}_{165}$, a splice variant rather than a proteolytic product of the full-length clone, maintains some heparin-binding capacity but can also readily diffuse and likely 
accounts for the majority of the angiogenic stimulatory properties of VEGF, whereas VEGF $_{121}$ is an easily diffusible splice variant of VEGF that can no longer bind to the extracellular matrix. Three additional VEGF forms were identified based on their homology to VEGF-A and were named VEGF-B, VEGF-C, and VEGF-D. VEGF-C and VEGF-D appear most important in lymphangiogenesis and have binding affinity for VEGFR-3 (also called flt-4). VEGF-A and VEGF-B have increased binding affinity for VEGFR-1 (Flt-1) and VEGFR-2 (Flk-1 or KDR). Although VEGF-A can bind both VEGFR-1 and VEGFR-2, most data suggest that binding of VEGF-A to VEGFR-2 accounts for the majority of the angiogenic stimulatory signal observed in vivo. VEGFR-1 may, in fact, be a decoy receptor with limited signaling capacity (Ho and Kuo 2007). Other receptors such as the neuropilins (NRP1 and NRP2) in the brain can compete with VEGF-A for the receptor (Miao et al. 1999; Klagsbrun et al. 2002). Because many preclinical and, especially, clinical studies of VEGF and VEGF inhibitors do not adequately address the varying roles of the cross talk between these different isoforms, splice variants, and receptors, negative outcomes of clinical trials may be the result of our poor understanding of these variables.

VEGF is produced by several cell types such as fibroblasts, inflammatory cells, and many tumor cells, often in response to increasing tumor hypoxia via the HIF-la pathway. Although endothelial cells express high levels of VEGFR-2, its expression can be found on other cell types as well. The lower density of VEGFR-2 receptors on non-endothelial cells may explain the apparent specificity of VEGF as a vascular mitogen (Matsumoto and Claesson-Welsh 2001). The importance of VEGF signaling through the VEGFR in neovascularization has been shown in many model systems (Kuo et al. 2001; Ferrara et al. 2003) and is supported by the significantly elevated levels of VEGF mRNA in many tumor types (Berger et al. 1995). Other diseases associated with elevation in VEGF such as inflammatory conditions, hemangiomas, arthritis, and retinopathy suggest that non-malignant cell types can up-regulate VEGF and may also be appropriate targets of VEGF inhibition (Folkman 1995).

\section{VEGF INHIBITORS IN CLINICAL TRIALS}

The development of highly specific inhibitors of both the VEGF ligand (bevacizumab, VEGF-Trap, ranibizumab) as well as the VEGF receptor (cediranib, pazopanib, sorafenib, sunitinib, vandetanib, axitinib, telatinib, semaxanib, motesanib, vatalanib, Zactima) relates to the central role that this pathway plays in disease (see Table 1) (Ahmed et al. 2004; Baka et al. 2006; Jain et al. 2006; Faivre et al. 2007; Tabernero 2007; Choueiri 2008; Dadgostar and Waheed 2008; Sloan and Scheinfeld 2008; Lindsay et al. 2009; Porta et al. 2009). Preclinical data for the activity of these (and many other) VEGF pathway inhibitors are beyond the scope of this review (Timar and Dome 2008). Based on promising single agent or combination therapy, many inhibitors have entered human clinical trials for a wide range of diseases and have been thoroughly reviewed (see Table 2) (Kowanetz and Ferrara 2006; Ho and Kuo 2007; Kourlas and Abrams 2007; Los et al. 2007).

The particular focus of clinical trials will be those using formal prospective clinical trial structures where the activity of the arm containing a VEGF inhibitor (usually in combination with traditional chemotherapy and/or radiation therapy) can be compared with the standard therapy alone (Kessler et al. 2010). Most trials of single-agent VEGF inhibitors have not produced sufficient activity to warrant approval except in certain specific diseases such as renal cell carcinoma (RCC).

Perhaps the most studied of the antiangiogenic agents, and the first to receive FDA approval in 2004, was bevacizumab (Avastin) (Grothey and Galanis 2009; Van Meter and Kim 2010). This recombinant humanized monoclonal antibody targets all of the isoforms of VEGF-A. When administered with irinotecan and bolus 5-FU/leucovorin (IFL) chemotherapy versus IFL alone as first-line therapy 
M.W. Kieran et al.

Table 1. VEGF/VEGFR agents completing prospective clinical trials

\begin{tabular}{lll}
\hline Name & Synonyms & \multicolumn{1}{c}{ Target } \\
\hline AG013736 & Axitinib & VEGFR1, 2, 3, PDGFR \\
AMG 706 & Motesanib & VEGFR1, 2, 3, PDGFR, cKit \\
AZD2171 & Cediranib & VEGFR1, 2, 3 \\
BAY 43-9006, sorafenib & Nexavar & RAF, VEGFR2, 3, PDGFR, ckit \\
BAY 57-9352 & Telatinib & VEGFR2, 3, PDGFR, c-kit \\
Bevacizumab & Avastin & VEGF \\
GW786034 & Pazopanib & VEGFR, PDGFR, cKit \\
HuMV833 & & VEGF \\
JNJ-26483327 & & EGFR, VEGFR3 \\
MLN518 & Tandutinib & Type III RTK \\
Pegaptanib aptamer & Macugen & VEGF \\
PKC412 & Midostaurin & Protein kinase C, VEGFR2 \\
PTK 787/ZK 222584 & Vatalanib & VEGFR1, 2, 3 \\
Ranibizumab & Lucentis & VEGF \\
SU11248 & Sunitinib & VEGFR, PDGFR, cKit \\
SU5416 & Semaxanib & VEGFR1, 2 \\
Sunitinib, SU11248 & Sutent & VEGFR, PDGR \\
Trap-Eye & & VEGF \\
VEGF Trap & Aflibercept & VEGF \\
ZD6474, Zactima & Vandetanib & VEGFR1, 2, 3, EGFR \\
\hline
\end{tabular}

for metastatic colorectal cancer, bevacizumabIFL improved median survival from 15.6 to $20.3(p<0.001)$, progression-free survival (6.2 to $10.6 \mathrm{mo}$ ), and time to progression (6.7 to $8.8 \mathrm{mo}$ ) (Hurwitz et al. 2004). Improvements in overall survival (10.8 vs. $12.9 \mathrm{mo}$ ) and time to progression (4.6 vs. $7.2 \mathrm{mo}$ ) have been reported in another phase III trial of oxaliplatin, leucovorin, and 5-fluorouricil (FOLFOX 4) with and without bevacizumab as second-line therapy for previously treated advanced colorectal cancer. Single-agent bevacizumab failed to show significant activity (Ho and Kuo 2007). Improved survival in phase III studies of advanced non-small-cell lung cancer (NSCLC) (overall survival 10.3 vs. $12.3 \mathrm{mo}, p=0.0075$ ) was also observed when bevacizumab was added to chemotherapy (Sandler et al. 2006). A phase III trial of bevacizumab and capecitabine compared with capecitabine alone improved the objective response rate $(9.1 \%$ vs. $19.8 \%, p=0.001$ ) in previously treated metastatic breast cancer patients, although significant improvements were not observed for either progression-free survival or overall survival (Miller et al. 2005a). A separate phase III trial of bevacizumab in combination with paclitaxel in newly diagnosed metastatic breast cancer showed improved objective response rates and progression-free survival, although overall survival data are still pending (Ho and Kuo 2007). In December of 2010, the FDA removed approval for the use of bevacizumab for metastatic breast cancer based on follow-up studies that failed to show the activity identified in earlier studies. This decision is being appealed by the company. Bevacizumab and interferon have also been approved for advanced RCC (Rini et al. 2008; Summers et al. 2010). Bevacizumab has also recently been approved for recurrent GBM (Cohen et al. 2009b).

Phase III trials showing activity for small molecule inhibitors of the VEGFR-2 receptor include sorafenib (BAY 43-9006) and sunitinib malate (Sutent). These orally bioavailable agents show broad-spectrum activity against numerous kinases including VEGF receptors. Sorafenib received FDA approval for advanced/ metastatic RCC based on phase III data showing 
VEGF Pathway in Cancer and Disease

Table 2. Clinical trials of VEGF/VEGFR inhibitors

\begin{tabular}{|c|c|c|c|c|}
\hline Name & Additional agents & Status & Disease & References \\
\hline AG013736 & & II & RCC & Rini et al. 2009 \\
\hline AMG 706 & & II & Thyroid cancer & Sherman et al. 2008 \\
\hline AMG 706 & & I & Solid tumor & Rosen et al. 2007 \\
\hline AZD2171 & & II & GBM & Batchelor et al. 2010 \\
\hline AZD2171 & Gefitinib & I & Solid tumors & van Cruijsen et al. 2010 \\
\hline AZD2171 & & I & AML & Fiedler et al. 2010 \\
\hline AZD2171 & & I & Solid tumors & Drevs et al. 2007 \\
\hline BAY 57-9352 & & I & Solid tumors & Eskens et al. 2009 \\
\hline Bevacizumab & Erlotinib & II & Biliary cancer & Lubner et al. 2010 \\
\hline Bevacizumab & Erlotinib & $\mathrm{I} / \mathrm{II}$ & Squamous cell cancer & Cohen et al. 2009a \\
\hline Bevacizumab & Erlotinib & II & Breast cancer & Dickler et al. 2008 \\
\hline Bevacizumab & $\begin{array}{l}\text { Metronomic } \\
\text { therapy }\end{array}$ & II & Breast cancer & Garcia-Saenz et al. 2008 \\
\hline Bevacizumab & $\pm \mathrm{IFN}-\alpha 2 \mathrm{~b}$ & II & Melanoma & Varker et al. 2007 \\
\hline Bevacizumab & $\begin{array}{l}\text { Oxaliplatin and } \\
\text { capecitabine }+ \\
\text { XRT }\end{array}$ & $\mathrm{I}$ & Rectal cancer & Czito et al. 2007 \\
\hline Bevacizumab & \pm Interferon-a & III & RCC & Rini et al. 2008 \\
\hline Bevacizumab & & III & $\mathrm{ADM}$ & Patel et al. 2008 \\
\hline Bevacizumab & & II & Ovarian & Burger et al. 2007 \\
\hline Bevacizumab & & III & $\mathrm{ADM}$ & Scott et al. 2007 \\
\hline Bevacizumab & + Gemcitabine & II & Pancreatic & Kindler et al. 2005 \\
\hline Bevacizumab & & I-Peds & Solid tumor & Glade Bender et al. 2008 \\
\hline Bevacizumab & + Irinotecan & II-Peds & HGG & Gururangan et al. 2010 \\
\hline GW786034 & & II & GBM & Iwamoto et al. 2010 \\
\hline GW786034 & & II & RCC & Hutson et al. 2010 \\
\hline HuMV833 & & I & Solid tumor & Jayson et al. 2005 \\
\hline JNJ-26483327 & & I & Solid tumors & Konings et al. 2010 \\
\hline MLN518 & & II & Renal cell & Shepard et al. 2010 \\
\hline Pegaptanib (aptamer) & & II & $\mathrm{ADM}$ & Apte et al. 2007 \\
\hline PKC412 & & $\mathrm{I}$ & Advanced cancer & Fabbro et al. 2000 \\
\hline PTK 787/ZK 222584 & Cetuximab & I & Solid tumors & Langenberg et al. 2010 \\
\hline PTK 787/ZK 222584 & Tem + XRT & $\mathrm{I} / \mathrm{II}$ & GBM & Brandes et al. 2010 \\
\hline PTK 787/ZK 222584 & $+\underset{\text { cisplatin }}{\text { Pemetrexed }}+$ & I & Solid tumor & Sharma et al. 2009 \\
\hline PTK 787/ZK 222584 & & I & $\begin{array}{l}\text { Myelofibrosis with } \\
\text { myeloid metaplasia }\end{array}$ & Giles et al. 2007 \\
\hline PTK 787/ZK 222584 & & I & AML & Roboz et al. 2006 \\
\hline PTK 787/ZK 222584 & & I & Liver metastases & Mross et al. 2005 \\
\hline PTK 787/ZK 222584 & & I & Advanced cancer & Thomas et al. 2005 \\
\hline Ranibizumab & & III & $\mathrm{ADM}$ & $\begin{array}{l}\text { Kaiser et al. 2007a,b; Boyer } \\
\text { et al. 2009; Bressler et al. } \\
\text { 2009; Brown et al. 2009; } \\
\text { Lalwani et al. 2009; } \\
\text { Campochiaro et al. 2010; } \\
\text { Sadda et al. } 2010\end{array}$ \\
\hline SU11248 & & II & NSCLC & $\begin{array}{l}\text { Socinski et al. 2008; Ping } \\
\text { et al. } 2010\end{array}$ \\
\hline SU11248 & & II & Cervical carcinoma & Mackay et al. 2010 \\
\hline
\end{tabular}


M.W. Kieran et al.

Table 2. Continued

\begin{tabular}{|c|c|c|c|c|}
\hline Name & Additional agents & Status & Disease & References \\
\hline SU11248 & & II & Head and neck & Fountzilas et al. 2010 \\
\hline SU11248 & & II & $\mathrm{RCC}$ & $\begin{array}{l}\text { Motzer et al. 2006; Polyzos } \\
\text { 2008; Kontovinis et al. } \\
2009\end{array}$ \\
\hline SU11248 & & II & $\begin{array}{l}\text { Neuroendocrine } \\
\text { cancer }\end{array}$ & Kulke et al. 2008 \\
\hline SU11248 & & II & Breast cancer & Burstein et al. 2008 \\
\hline SU11248 & & II & Urothelial cancer & Bradley et al. 2007 \\
\hline SU11248 & & I & AML & Fiedler et al. 2005 \\
\hline SU5416 & & I-peds & Brain tumor & Kieran et al. 2009 \\
\hline SU5416 & + Irinotecan & I & Colorectal & Hoff et al. 2006 \\
\hline SU5416 & + Thalidomide & II & Melanoma & Mita et al. 2007 \\
\hline SU5416 & & II & Head and neck & Fury et al. 2007 \\
\hline SU5416 & & I & Solid tumor & O’Donnell et al. 2005 \\
\hline SU5416 & & I & Head and neck & Cooney et al. 2005 \\
\hline SU5416 & & I & Sarcoma & Heymach et al. 2004 \\
\hline SU5416 & & II & Melanoma & Peterson et al. 2004 \\
\hline SU5416 & & II & Prostate cancer & Stadler et al. 2004 \\
\hline SU5416 & & II & AML & O'Farrell et al. 2004 \\
\hline SU5416 & & II & Multiple myeloma & Zangari et al. 2004 \\
\hline SU5416 & + IFN & II & $\mathrm{RCC}$ & Lara et al. 2003 \\
\hline SU5416 & & II & AML & Fiedler et al. 2003 \\
\hline SU5416 & & II & RCC, sarcoma & Kuenen et al. 2003 \\
\hline SU5416 & & II & $\begin{array}{l}\text { Myeloproliferative } \\
\text { disease }\end{array}$ & Giles et al. 2003a \\
\hline SU5416 & & II & AML & Giles et al. 2003b \\
\hline Trap-Eye & & I & $\mathrm{ADM}$ & Nguyen et al. 2009 \\
\hline VEGF Trap & & I & Solid tumors & Lockhart et al. 2010 \\
\hline ZD6474, Zactima & $\begin{array}{c} \pm \text { Paclitaxel }+ \\
\text { carboplatin }\end{array}$ & II & NSCLC & Heymach et al. 2008 \\
\hline ZD6474, Zactima & & II & Multiple myeloma & Kovacs et al. 2006 \\
\hline ZD6474, Zactima & & I & Solid tumors & Holden et al. 2005 \\
\hline ZD6474, Zactima & & II & Breast cancer & Miller et al. 2005b \\
\hline ZD6474, Zactima & $+\mathrm{XRT}$ & II-Peds & HGG & Broniscer et al. 2010 \\
\hline ZD6474, Zactima & $\begin{array}{l}\text { Vinorelbine/ } \\
\text { cisplatin or } \\
\text { gemcitibine/ } \\
\text { cisplatin }\end{array}$ & I & NSCLC & Blackhall et al. 2010 \\
\hline ZD6474, Zactima & Docetaxel \pm & III & NSCLC & Herbst et al. 2010 \\
\hline ZD6474, Zactima & & II & $\begin{array}{l}\text { Medullary thyroid } \\
\text { cancer }\end{array}$ & Robinson et al. 2010a \\
\hline ZD6474, Zactima & $\begin{array}{l}+ \text { XRT }+ \\
\text { temozolomide }\end{array}$ & I & GBM & Drappatz et al. 2010 \\
\hline ZD6474, Zactima & & II & Ovarian & Annunziata et al. 2010 \\
\hline ZD6474, Zactima & & II & $\begin{array}{l}\text { Medullary thyroid } \\
\text { cancer }\end{array}$ & Wells et al. 2010 \\
\hline ZD6474, Zactima & $\begin{array}{l}+ \text { Docetaxel/ } \\
\text { prednisolone }\end{array}$ & II & Prostate & Horti et al. 2009 \\
\hline ZD6474, Zactima & Versus gefitinib & II & NSCLC & Natale et al. 2009 \\
\hline
\end{tabular}


Table 2. Continued

\begin{tabular}{llcll}
\hline Name & Additional agents & Status & Disease & \multicolumn{1}{c}{ References } \\
\hline ZD6474, Zactima & + FOLFIRI & I & Colorectal & Saunders et al. 2009 \\
ZD6474, Zactima & + Pemetrexed & I & NSCLC & de Boer et al. 2009 \\
ZD6474, Zactima & + mFOLFOX6 & I & Colorectal & Michael et al. 2009 \\
ZD6474, Zactima & & II & NSCLC & Arnold et al. 2007; Kiura \\
& & & & et al. 2008 \\
ZD6474, Zactima & \pm Docetaxel & II & NSCLC & Heymach et al. 2007 \\
ZD6474, Zactima & & I & Solid tumor & Tamura et al. 2006 \\
ZD6474, Zactima & & II & NSCLC & Lee 2005 \\
\hline
\end{tabular}

improved progression-free survival (2.8 vs. 5.5 wk, $p<0.001)$ and overall survival (15.9 vs. $19.3 \mathrm{mo}, p=0.02$ ) (Escudier et al. 2007). It has also received approval for hepatocellular carcinoma (Rossi et al. 2010). Similarly, sunitinib received FDA approval in early 2006 for imatinib-resistant gastrointestinal stromal tumors (GIST) and for metastatic renal cell carcinoma (RCC), showing improved progression-free survival for sunitinib versus IFN- $\alpha$ (11 vs. $5 \mathrm{mo}$ ), as well as objective response rate (31\% vs. $6 \%)$ (Motzer et al. 2007). The broad spectrum of activity of these two inhibitors precludes clear attribution of their activity just to inhibition of the VEGF pathway.

VEGF inhibitors have also been successfully used for treatment of the wet form of age-related macular degeneration (AMD). A pegylated oligonucleotide aptamer selectively targeting VEGF165 called pegaptanib sodium (Macugen) and a recombinant, humanized anti-VEGF Fab fragment called ranibizumab (Lucentis) are both FDA approved for treatment of this disease (Gryziewicz 2005; Ciulla and Rosenfeld 2009). Not only have patients showed improvement in disease, but also many have shown significant improvement in vision, even when compared with other approaches such as photodynamic therapy (Rosenfeld et al. 2006).

Consideration of the unique environment for different tumors will likely affect the choice, activity, and toxicity of different antiangiogenic agents (Josson et al. 2010). Approaches for different diseases should consider these differences including breast (Chan 2009), brain (Miletic et al. 2009), renal cell (Bukowski 2009; Motzer and Molina 2009), NSCLC (Aita et al. 2008), and pancreas (Philip 2008), to name a few.

\section{TOXICITIES OF VEGF PATHWAY INHIBITORS}

In general, antiangiogenic agents have been well tolerated. Because many of the initial clinical trials of VEGF inhibitors, especially small molecule inhibitors, had several off-target effects, the actual toxicity profile of this class of agents has been difficult to assess. With more specific agents now in the clinic, a picture is emerging that suggests that, in general, VEGF pathway inhibitors are well tolerated, whether administered orally, intravenously, or intraocularly. Common toxicities thought to be related to on-target effects include fatigue, hypertension (Izzedine et al. 2007, 2009; Pande et al. 2007), proteinuria, delayed wound healing, and chemical hypothyroidism (often without clinical symptoms) (Veronese et al. 2006; Boehm et al. 2010; Geiger-Gritsch et al. 2010; Robinson et al. 2010b). Several rare side effects have also been reported in multiple trials and include bleeding and/or thrombosis (which can be severe or fatal), intestinal and nasal septal perforation (Hapani et al. 2009), effects on growth plates (Hall et al. 2006), and posterior reversible encephalopathy syndrome (PRES), also known as reversible posterior leukoencephalopathy syndrome (RPLS) (Artunay et al. 2010). Initial concerns about frequent severe and fatal hemorrhages have not been observed clinically for most tumor types, although this potential side effect continues to be of concern, particularly in certain tumor subtypes (Hapani 
M.W. Kieran et al.

et al. 2010). It is still not clear whether patients with severe side effects are poor or better responders to therapy.

\section{ASSESSMENT OF THE ANGIOGENIC RESPONSE}

Critical to the determination of activity of a clinical inhibitor, including those of the VEGF pathway, are methodologies that accurately detect the antitumor effect of the agents being tested. Overall survival and time to progression remain important determinants that can address the relative clinical importance of therapies and remain the gold standards. Treatments that cause significant tumor response followed by equally rapid tumor progression without any impact on time to progression or survival are less useful than those that may only stabilize the tumor but result in prolongation of survival. As discussed briefly above, VEGF was originally identified for its effect on permeability (VPF) (Senger et al. 1983), presumably the result of its stimulation of endothelial cell proliferation, which requires the cells to round up as they prepare for mitosis. Endothelial cells that break their junctions with neighboring endothelial cells will therefore allow some of the intravascular liquid to leak into the surrounding tissue. When the VEGF inhibitor bevacizumab was initially tested in patients with glioblastoma multiforme, a disease known to have significantly elevated VEGF levels and for which neovascularization is part of the diagnostic criteria of the disease, response rates by MRI of $60 \%-70 \%$ were reported (Vredenburgh et al. 2007). In hindsight, the "response" observed in these patients was likely related more to the decreasing permeability effect when VEGF is sequestered by bevacizumab than actual tumor "response" related to tumor cell kill (Verhoeff et al. 2009). Significant reduction in contrast enhancement (the response) can be observed within a day of treating patients with VEGF inhibitors (Batchelor et al. 2007) and can be lost (the resistance) when the inhibition is released. Proof that tumor escape has not actually occurred can be easily shown by restarting the inhibitor and getting the "response" back, something that has been observed during drug holidays for therapyassociated toxicities (Batchelor et al. 2007). This effect will be of critical importance as we continue to use radiologic tumor assessment to guide activity of this class of drugs and has led to the proposal in adults of new response assessment criteria that attempt to take some of this effect into account (Thompson et al. 2010; Wen et al. 2010).

\section{RESISTANCE TO VEGF PATHWAY THERAPY}

As correctly predicted in the original hypothesis of Dr. Folkman, ample preclinical data now support the critical importance of angiogenesis as a fundamental process of tumor progression. Because the neo-angiogenic stimulus is generated by the tumor through secretion of factors that can induce new vessel formation by acting on endothelial cells, it was predicted that resistance would not occur (Boehm et al. 1997). This was based on the assumption that endothelial cells responding to tumor secretion of cytokines are fundamentally normal cells, cannot mutate, and thus cannot evade therapeutic intervention. Unfortunately, clinical experience has not been as optimistic. Even in the clinical trials showing activity for inhibitors of the VEGF pathway based on response, time to progression, or overall survival, the vast majority of patients eventually succumb to their disease. Understanding these "resistance" mechanisms will therefore be critical for the long-term use of this class of inhibitors. Two major types of resistance-extrinsic and intrinsic-are presented below, although others may come to light as more attention is focused on this field. Others have defined resistance patterns in different ways that need to be discussed and evaluated (Ton and Jayson 2004; Bergers and Hanahan 2008; Azam et al. 2010).

\section{Go-Around (Extrinsic) Resistance}

1. The easiest resistance mechanisms to understand are those that do not reduce the activity of the inhibitor or alter the primary effect on the target, but rather provide a simple 
redundant signal that makes the one being inhibited no longer essential. Thus, inhibition of the VEGF pathway can be easily overcome by up-regulation of other VEGFindependent pathways such as bFGF, IL-8, or any combination of the 40 or so angiogenic cytokines that have been discovered to date (Leek et al. 1994; Yan et al. 2006; Gerber et al. 2009; Voss et al. 2010). This type of resistance was to be expected. Redundancy in cellular signaling is observed in a large number of biological pathways and accounts for the resistance to many drugs including those for EGF, PDGF, and mTOR (Kornblau et al. 2006; Tabernero 2007). These alternative angiogenic pathways may also account for the very poor up-front response of certain tumor types to antiangiogenic therapy. Tumors that up-regulate multiple pathways early in their genesis would not be dependent on any single inhibitor and would thus fail to respond from the outset. The ability of tumors to express more than one angiogenic cytokine has been shown for many tumor types (Karcher et al. 2006; Samaras et al. 2009). Consistent with this idea has been the improved activity of combination approaches in preclinical models (Bozec et al. 2008). To be successful in the long term, a detailed understanding of all (or most) of the angiogenic cascades operating to maintain tumor growth will need to be identified and targeted simultaneously if this form of resistance is to be avoided (Wary 2004).

2. Another modality for getting around the blockage generated by VEGF pathway inhibition is to coopt existing blood vessels so that angiogenesis is no longer required. This is best visualized in the brain, where malignant gliomas can grow along existing blood vessels rather than as a discrete mass, a process called "gliomatosis cerebri." Mechanistically, this might be related to the tumor's response to hypoxia induced by anti-VEGF therapy in which promigratory and invasive phenotypes are favored to reach areas of improved oxygenation. Interestingly, there is some evidence to suggest that gliomatosis cerebri can occur with increased frequency in patients treated with VEGF inhibitors (Norden et al. 2008).

3. Tumors can up-regulate the metabolism of antiangiogenic agents through a variety of mechanisms, all of which would result in loss of response to therapy. Increased clearance of a drug, decreased penetration into the target cell (e.g., by change in local $\mathrm{pH}$ ), or increased proteolytic degradation of protein inhibitors (thrombospondin, endostatin as examples) or antibodies (bevacizumab, VEGF-Trap as examples) are all possible mechanisms (Kitamura et al. 2008). Although patients are often referred to as having developed "resistance" when they initially respond to a drug but then lose the response, it is important to recognize that this effect is not actual endothelial or target resistance.

4. Finally, initial reports that tumor cells themselves could act as endothelial cells ensuring functional tube formation without a complete endothelial cell response is another potential method of getting around therapeutic antiangiogenic interventions (Hendrix et al. 2003; Barrett et al. 2005; Fujimoto et al. 2006). Follow-up studies have failed to show a strong or clinically significant role for this mechanism.

\section{Classic Endothelial Cell (Intrinsic) Resistance}

As initially predicted, the ability of normal endothelial cells, even those responding to tumor-induced angiogenic stimuli, appears limited. Tumor-associated endothelial cells have been reported to take up tumor DNA, which, in turn, could assist with development of true intrinsic resistance (Hida et al. 2004). Although this resistance mechanism must be considered as a possibility, it does not currently appear to be a major issue either in preclinical models or human response to antiangiogenic therapy.

\section{SUMMARY}

Antiangiogenic strategies for the control of tumor-mediated angiogenesis have progressed dramatically over the last 40 years. Multiple 
M.W. Kieran et al.

inhibitors are in clinical trials, and several have been approved for use in the United States and Europe. Some of the initial excitement for this class of drugs has waned despite less than a decade of real experience. This has resulted from an underestimation of the complexity of neovascularization including the number of cell types and pathways involved, the adaptive response of established tumors once therapy is initiated, and the availability of a small set of inhibitors, many with limited activity, poor specificity, and great toxicity. In this regard, it is possible that antiangiogenic therapy may reveal its best efficacy when used on early tumors which have yet to convert or have just converted to angiogenic tumors. Such "proactive" trials are hard to conduct but, we hope, will be pursued. The field of oncology did not give up on radiation therapy or on chemotherapy within the first 10 years of their use, despite their limited impact on survival. Rather, as we began to understand the complexity of cancer, the opportunity for improved drug development and combinations including surgery, radiation, and chemotherapy have begun to result in cures. A similar maturation is needed in the field of anti-angiogenesis and has now begun. As combination approaches gain acceptance and are based on a more precise understanding of the subtle angiogenic profiles specific to any individual's tumor, our ability to select patients who are most likely to respond to VEGF targeting will occur. This will also allow therapy to take into account the escape mechanisms that the tumor might use with appropriate adaptation of the therapeutic plan.

Antiangiogenic therapy did not fail to meet our expectations-rather, our expectations were unrealistic. The original proposal by Dr. Folkman recognized the association of neovascularization and tumor growth, that endothelial cells are a unique "ecosystem" within the tumor, that tumor cells regulate endothelial cell proliferation, and that this, in turn, can affect the rate of tumor growth (Folkman 1971). All of this occurred before the discovery of either proangiogenic cytokines or inhibitors. Although Dr. Folkman was excited by the promise of VEGF-targeted therapy for cancer and other diseases, he also recognized the complexity of tumor-mediated angiogenesis. He therefore saw this approach as a success in laying the foundation for future research, understanding, and clinical intervention. So should we!

\section{REFERENCES}

Ahmed SI, Thomas AL, Steward WP. 2004. Vascular endothelial growth factor (VEGF) inhibition by small molecules. J Chemother 16: 59-63.

Ahn GO, Brown JM. 2009. Role of endothelial progenitors and other bone marrow-derived cells in the development of the tumor vasculature. Angiogenesis 12: 159-164.

Aita M, Fasola G, Defferrari C, Brianti A, Bello MG, Follador A, Sinaccio G, Pronzato P, Grossi F. 2008. Targeting the VEGF pathway: Antiangiogenic strategies in the treatment of non-small cell lung cancer. Crit Rev Oncol Hematol 68: 183-196.

Annunziata CM, Walker AJ, Minasian L, Yu M, Kotz H, Wood BJ, Calvo K, Choyke P, Kimm D, Steinberg SM, et al. 2010. Vandetanib, designed to inhibit VEGFR2 and EGFR signaling, had no clinical activity as monotherapy for recurrent ovarian cancer and no detectable modulation of VEGFR2. Clin Cancer Res 16: 664-672.

Apte RS, Modi M, Masonson H, Patel M, Whitfield L, Adamis AP. 2007. Pegaptanib 1-year systemic safety results from a safety-pharmacokinetic trial in patients with neovascular age-related macular degeneration. Ophthalmology 114: 1702-1712.

Arnold AM, Seymour L, Smylie M, Ding K, Ung Y, Findlay B, Lee CW, Djurfeldt M, Whitehead M, Ellis P, et al. 2007. Phase II study of vandetanib or placebo in small-cell lung cancer patients after complete or partial response to induction chemotherapy with or without radiation therapy: National Cancer Institute of Canada Clinical Trials Group Study BR.20. J Clin Oncol 25: 4278-4284.

Artunay O, Yuzbasioglu E, Rasier R, Sengul A, Bahcecioglu H. 2010. Posterior reversible encephalopathy syndrome after intravitreal bevacizumab injection in patient with choroidal neovascular membrane secondary to agerelated maculopathy. J Ocul Pharmacol Ther 26: 301-303.

Azam F, Mehta S, Harris AL. 2010. Mechanisms of resistance to antiangiogenesis therapy. Eur J Cancer 46: 1323-1332.

Baka S, Clamp AR, Jayson GC. 2006. A review of the latest clinical compounds to inhibit VEGF in pathological angiogenesis. Expert Opin Ther Targets 10: 867-876.

Barrett JM, Mangold KA, Jilling T, Kaul KL. 2005. Bi-directional interactions of prostate cancer cells and bone marrow endothelial cells in three-dimensional culture. Prostate 64: 75-82.

Batchelor TT, Sorensen AG, di Tomaso E, Zhang WT, Duda DG, Cohen KS, Kozak KR, Cahill DP, Chen PJ, Zhu M, et al. 2007. AZD2171, a pan-VEGF receptor tyrosine kinase inhibitor, normalizes tumor vasculature and alleviates edema in glioblastoma patients. Cancer Cell 11: 83-95.

Batchelor TT, Duda DG, di Tomaso E, Ancukiewicz M, Plotkin SR, Gerstner E, Eichler AF, Drappatz J, Hochberg FH, 
Benner T, et al. 2010. Phase II study of cediranib, an oral pan-vascular endothelial growth factor receptor tyrosine kinase inhibitor, in patients with recurrent glioblastoma. J Clin Oncol 28: 2817-2823.

Berger DP, Herbstritt L, Dengler WA, Marme D, Mertelsmann R, Fiebig HH. 1995. Vascular endothelial growth factor (VEGF) mRNA expression in human tumor models of different histologies. Ann Oncol 6: 817-825.

Bergers G, Hanahan D. 2008. Modes of resistance to antiangiogenic therapy. Nat Rev Cancer 8: 592-603.

Bhadada SV, Goyal BR, Patel MM. 2010. Angiogenic targets for potential disorders. Fundam Clin Pharmacol 25: 29-47.

Blackhall FH, O’Brien M, Schmid P, Nicolson M, Taylor P, Milenkova T, Kennedy SJ, Thatcher N. 2010. A phase I study of Vandetanib in combination with vinorelbine/ cisplatin or gemcitabine/cisplatin as first-line treatment for advanced non-small cell lung cancer. J Thorac Oncol 5: $1285-1288$.

Boehm T, Folkman J, Browder T, O’Reilly MS. 1997. Antiangiogenic therapy of experimental cancer does not induce acquired drug resistance [see comments]. Nature 390: 404-407.

Boehm S, Rothermundt C, Hess D, Joerger M. 2010. Antiangiogenic drugs in oncology: A focus on drug safety and the elderly-A mini-review. Gerontology 56: 303-309.

Boyer DS, Heier JS, Brown DM, Francom SF, Ianchulev T, Rubio RG. 2009. A Phase IIIb study to evaluate the safety of ranibizumab in subjects with neovascular age-related macular degeneration. Ophthalmology 116: 1731-1739.

Bozec A, Gros FX, Penault-Llorca F, Formento P, Cayre A, Dental C, Etienne-Grimaldi MC, Fischel JL, Milano G. 2008. Vertical VEGF targeting: A combination of ligand blockade with receptor tyrosine kinase inhibition. Eur J Cancer 44: $1922-1930$.

Bradley DA, Dunn R, Nanus D, Stadler W, Dreicer R, Rosenberg J, Smith DC, Hussain M. 2007. Randomized, double-blind, placebo-controlled phase II trial of maintenance sunitinib versus placebo after chemotherapy for patients with advanced urothelial carcinoma: Scientific rationale and study design. Clin Genitourin Cancer 5: $460-463$.

Brandes AA, Stupp R, Hau P, Lacombe D, Gorlia T, Tosoni A, Mirimanoff RO, Kros JM, van den Bent MJ. 2010. EORTC study 26041-22041: Phase I/II study on concomitant and adjuvant temozolomide (TMZ) and radiotherapy (RT) with PTK787/ZK222584 (PTK/ZK) in newly diagnosed glioblastoma. Eur J Cancer 46: 348-354.

Bressler NM, Chang TS, Fine JT, Dolan CM, Ward J. 2009. Improved vision-related function after ranibizumab vs photodynamic therapy: A randomized clinical trial. Arch Ophthalmol 127: 13-21.

Broniscer A, Baker JN, Tagen M, Onar-Thomas A, Gilbertson RJ, Davidoff AM, Panandiker AS, Leung W, Chin TK, Stewart CF, et al. 2010. Phase I study of vandetanib during and after radiotherapy in children with diffuse intrinsic pontine glioma. J Clin Oncol 28: 4762-4768.

Brown DM, Michels M, Kaiser PK, Heier JS, Sy JP, Ianchulev T. 2009. Ranibizumab versus verteporfin photodynamic therapy for neovascular age-related macular degeneration: Two-year results of the ANCHOR study. Ophthalmology 116: 57-65.
Bukowski RM. 2009. Targeted therapies: Bevacizumab and interferon- $\alpha$ in metastatic renal-cell carcinoma. Nat Rev Clin Oncol 6: 253-254.

Burger RA, Sill MW, Monk BJ, Greer BE, Sorosky JI. 2007. Phase II trial of bevacizumab in persistent or recurrent epithelial ovarian cancer or primary peritoneal cancer: A Gynecologic Oncology Group Study. J Clin Oncol 25: 5165-5171.

Burstein HJ, Elias AD, Rugo HS, Cobleigh MA, Wolff AC, Eisenberg PD, Lehman M, Adams BJ, Bello CL, DePrimo SE, et al. 2008. Phase II study of sunitinib malate, an oral multitargeted tyrosine kinase inhibitor, in patients with metastatic breast cancer previously treated with an anthracycline and a taxane. J Clin Oncol 26: 1810-1816.

Campochiaro PA, Heier JS, Feiner L, Gray S, Saroj N, Rundle AC, Murahashi WY, Rubio RG. 2010. Ranibizumab for macular edema following branch retinal vein occlusion: Six-month primary end point results of a phase III study. Ophthalmology 117: 1102-1112.

Cao Y. 2009. Tumor angiogenesis and molecular targets for therapy. Front Biosci 14: 3962-3973.

Chan A. 2009. Antiangiogenic therapy for metastatic breast cancer: Current status and future directions. Drugs 69: $167-181$.

Choueiri TK. 2008. Axitinib, a novel anti-angiogenic drug with promising activity in various solid tumors. Curr Opin Investig Drugs 9: 658-671.

Ciulla TA, Rosenfeld PJ. 2009. Antivascular endothelial growth factor therapy for neovascular age-related macular degeneration. Curr Opin Ophthalmol 20: 158-165.

Cohen EE, Davis DW, Karrison TG, Seiwert TY, Wong SJ, Nattam S, Kozloff MF, Clark JI, Yan DH, Liu W, et al. 2009a. Erlotinib and bevacizumab in patients with recurrent or metastatic squamous-cell carcinoma of the head and neck: A phase I/II study. Lancet Oncol 10: 247-257.

Cohen MH, Shen YL, Keegan P, Pazdur R. 2009b. FDA drug approval summary: Bevacizumab (Avastin) as treatment of recurrent glioblastoma multiforme. Oncologist 14: 1131-1138.

Cooney MM, Tserng KY, Makar V, McPeak RJ, Ingalls ST, Dowlati A, Overmoyer B, McCrae K, Ksenich P, Lavertu P, et al. 2005. A phase IB clinical and pharmacokinetic study of the angiogenesis inhibitor SU5416 and paclitaxel in recurrent or metastatic carcinoma of the head and neck. Cancer Chemother Pharmacol 55: 295-300.

Czito BG, Bendell JC, Willett CG, Morse MA, Blobe GC, Tyler DS, Thomas J, Ludwig KA, Mantyh CR, Ashton J, et al. 2007. Bevacizumab, oxaliplatin, and capecitabine with radiation therapy in rectal cancer: Phase I trial results. Int J Radiat Oncol Biol Phys 68: 472-478.

Dadgostar H, Waheed N. 2008. The evolving role of vascular endothelial growth factor inhibitors in the treatment of neovascular age-related macular degeneration. Eye (Lond) 22: 761-767.

de Boer R, Humblet Y, Wolf J, Nogova L, Ruffert K, Milenkova T, Smith R, Godwood A, Vansteenkiste J. 2009 An open-label study of vandetanib with pemetrexed in patients with previously treated non-small-cell lung cancer. Ann Oncol 20: 486-491.

De Val S, Black BL. 2009. Transcriptional control of endothelial cell development. Dev Cell 16: 180-195. 
M.W. Kieran et al.

Diaz-Flores L, Gutierrez R, Madrid JF, Varela H, Valladares F, Acosta E, Martin-Vasallo P, Diaz-Flores L Jr. 2009. Pericytes. Morphofunction, interactions and pathology in a quiescent and activated mesenchymal cell niche. Histol Histopathol 24: 909-969.

Dickler MN, Rugo HS, Eberle CA, Brogi E, Caravelli JF, Panageas KS, Boyd J, Yeh B, Lake DE, Dang CT, et al. 2008. A phase II trial of erlotinib in combination with bevacizumab in patients with metastatic breast cancer. Clin Cancer Res 14: 7878-7883.

Drappatz J, Norden AD, Wong ET, Doherty LM, Lafrankie DC, Ciampa A, Kesari S, Sceppa C, Gerard M, Phan P, et al. 2010. Phase I study of vandetanib with radiotherapy and temozolomide for newly diagnosed glioblastoma. Int J Radiat Oncol Biol Phys 78: 85-90.

Drevs J, Siegert P, Medinger M, Mross K, Strecker R, Zirrgiebel U, Harder J, Blum H, Robertson J, Jurgensmeier JM, et al. 2007. Phase I clinical study of AZD2171, an oral vascular endothelial growth factor signaling inhibitor, in patients with advanced solid tumors. J Clin Oncol 25: 3045-3054.

Dvorak HF. 2005. Angiogenesis: Update 2005. J Thromb Haemost 3: 1835-1842.

Escudier B, Eisen T, Stadler WM, Szczylik C, Oudard S, Siebels M, Negrier S, Chevreau C, Solska E, Desai AA, et al. 2007. Sorafenib in advanced clear-cell renal-cell carcinoma. N Engl J Med 356: 125-134.

Eskens FA, Steeghs N, Verweij J, Bloem JL, Christensen O, van Doorn L, Ouwerkerk J, de Jonge MJ, Nortier JW, Kraetzschmar J, et al. 2009. Phase I dose escalation study of telatinib, a tyrosine kinase inhibitor of vascular endothelial growth factor receptor 2 and 3, platelet-derived growth factor receptor $\beta$, and c-Kit, in patients with advanced or metastatic solid tumors. J Clin Oncol 27: 4169-4176.

Fabbro D, Ruetz S, Bodis S, Pruschy M, Csermak K, Man A, Campochiaro P, Wood J, O’Reilly T, Meyer T. 2000. PKC412-a protein kinase inhibitor with a broad therapeutic potential. Anticancer Drug Des 15: 17-28.

Faivre S, Demetri G, Sargent W, Raymond E. 2007. Molecular basis for sunitinib efficacy and future clinical development. Nat Rev Drug Discov 6: 734-745.

Ferrara N, Henzel WJ. 1989. Pituitary follicular cells secrete a novel heparin-binding growth factor specific for vascular endothelial cells. Biochem Biophys Res Commun 161: 851-858.

Ferrara N, Gerber HP, LeCouter J. 2003. The biology of VEGF and its receptors. Nat Med 9: 669-676.

Fiedler W, Mesters R, Tinnefeld H, Loges S, Staib P, Duhrsen U, Flasshove M, Ottmann OG, Jung W, Cavalli F, et al. 2003. A phase 2 clinical study of SU5416 in patients with refractory acute myeloid leukemia. Blood 102: 2763-2767.

Fiedler W, Serve H, Dohner H, Schwittay M, Ottmann OG, O'Farrell AM, Bello CL, Allred R, Manning WC, Cherrington JM, et al. 2005. A phase 1 study of SU11248 in the treatment of patients with refractory or resistant acute myeloid leukemia (AML) or not amenable to conventional therapy for the disease. Blood 105: 986-993.

Fiedler W, Mesters R, Heuser M, Ehninger G, Berdel WE, Zirrgiebel U, Robertson JD, Puchalski TA, Collins B, Jurgensmeier JM, et al. 2010. An open-label, Phase I study of cediranib (RECENTIN) in patients with acute myeloid leukemia. Leuk Res 34: 196-202.

Folkman J. 1971. Tumor angiogenesis: Therapeutic implications. N Engl J Med 285: 1182-1186.

Folkman J. 1995. Angiogenesis in cancer, vascular, rheumatoid and other disease. Nat Med 1: 27-31.

Fountzilas G, Fragkoulidi A, Kalogera-Fountzila A, Nikolaidou M, Bobos M, Calderaro J, Andreiuolo F, Marselos M. 2010. A phase II study of sunitinib in patients with recurrent and/or metastatic non-nasopharyngeal head and neck cancer. Cancer Chemother Pharmacol 65: 649-660.

Fujimoto A, Onodera H, Mori A, Nagayama S, Yonenaga Y, Tachibana T. 2006. Tumour plasticity and extravascular circulation in ECV304 human bladder carcinoma cells. Anticancer Res 26: 59-69.

Fury MG, Zahalsky A, Wong R, Venkatraman E, Lis E, Hann L, Aliff T, Gerald W, Fleisher M, Pfister DG. 2007. A Phase II study of SU5416 in patients with advanced or recurrent head and neck cancers. Invest New Drugs 25: 165-172.

Garcia-Saenz JA, Martin M, Calles A, Bueno C, Rodriguez L, Bobokova J, Custodio A, Casado A, Diaz-Rubio E. 2008. Bevacizumab in combination with metronomic chemotherapy in patients with anthracycline- and taxanerefractory breast cancer. J Chemother 20: 632-639.

Geiger-Gritsch S, Stollenwerk B, Miksad R, Guba B, Wild C, Siebert U. 2010. Safety of bevacizumab in patients with advanced cancer: A meta-analysis of randomized controlled trials. Oncologist 15: 1179-1191.

Gerber PA, Hippe A, Buhren BA, Muller A, Homey B. 2009. Chemokines in tumor-associated angiogenesis. Biol Chem 390: 1213-1223.

Giles FJ, Cooper MA, Silverman L, Karp JE, Lancet JE, Zangari M, Shami PJ, Khan KD, Hannah AL, Cherrington JM, et al. 2003a. Phase II study of SU5416 - a smallmolecule, vascular endothelial growth factor tyrosinekinase receptor inhibitor-in patients with refractory myeloproliferative diseases. Cancer 97: 1920-1928.

Giles FJ, Stopeck AT, Silverman LR, Lancet JE, Cooper MA, Hannah AL, Cherrington JM, O'Farrell AM, Yuen HA, Louie SG, et al. 2003b. SU5416, a small molecule tyrosine kinase receptor inhibitor, has biologic activity in patients with refractory acute myeloid leukemia or myelodysplastic syndromes. Blood 102: 795-801.

Giles FJ, List AF, Carroll M, Cortes JE, Valickas J, Chen BL, Masson E, Jacques C, Laurent D, Albitar M, et al. 2007. PTK787/ZK 222584, a small molecule tyrosine kinase receptor inhibitor of vascular endothelial growth factor (VEGF), has modest activity in myelofibrosis with myeloid metaplasia. Leuk Res 31: 891-897.

Glade Bender JL, Adamson PC, Reid JM, Xu L, Baruchel S, Shaked Y, Kerbel RS, Cooney-Qualter EM, Stempak D, Chen HX, et al. 2008. Phase I trial and pharmacokinetic study of bevacizumab in pediatric patients with refractory solid tumors: A Children's Oncology Group Study. J Clin Oncol 26: 399-405.

Grothey A, Galanis E. 2009. Targeting angiogenesis: Progress with anti-VEGF treatment with large molecules. Nat Rev Clin Oncol 6: 507-518.

Gryziewicz L. 2005. Regulatory aspects of drug approval for macular degeneration. Adv Drug Deliv Rev 57: 2092 2098. 
Gururangan S, Chi SN, Young Poussaint T, Onar-Thomas A, Gilbertson RJ, Vajapeyam S, Friedman HS, Packer RJ, Rood BN, Boyett JM, et al. 2010. Lack of efficacy of bevacizumab plus irinotecan in children with recurrent malignant glioma and diffuse brainstem glioma: A Pediatric Brain Tumor Consortium study. J Clin Oncol 28: 3069-3075.

Hall AP, Westwood FR, Wadsworth PF. 2006. Review of the effects of anti-angiogenic compounds on the epiphyseal growth plate. Toxicol Pathol 34: 131-147.

Hapani S, Chu D, Wu S. 2009. Risk of gastrointestinal perforation in patients with cancer treated with bevacizumab: A meta-analysis. Lancet Oncol 10: 559-568.

Hapani S, Sher A, Chu D, Wu S. 2010. Increased risk of serious hemorrhage with bevacizumab in cancer patients: A meta-analysis. Oncology 79: 27-38.

Hendrix MJ, Seftor EA, Hess AR, Seftor RE. 2003. Vasculogenic mimicry and tumour-cell plasticity: Lessons from melanoma. Nat Rev Cancer 3: 411-421.

Herbst RS, Sun Y, Eberhardt WE, Germonpre P, Saijo N, Zhou C, Wang J, Li L, Kabbinavar F, Ichinose Y, et al. 2010. Vandetanib plus docetaxel versus docetaxel as second-line treatment for patients with advanced non-small-cell lung cancer (ZODIAC): A double-blind, randomised, phase 3 trial. Lancet Oncol 11: 619-626.

Heymach JV, Desai J, Manola J, Davis DW, McConkey DJ, Harmon D, Ryan DP, Goss G, Quigley T, Van den Abbeele $\mathrm{AD}$, et al. 2004. Phase II study of the antiangiogenic agent SU5416 in patients with advanced soft tissue sarcomas. Clin Cancer Res 10: 5732-5740.

Heymach JV, Johnson BE, Prager D, Csada E, Roubec J, Pesek M, Spasova I, Belani CP, Bodrogi I, Gadgeel S, et al. 2007. Randomized, placebo-controlled phase II study of vandetanib plus docetaxel in previously treated non small-cell lung cancer. J Clin Oncol 25: 4270-4277.

Heymach JV, Paz-Ares L, De Braud F, Sebastian M, Stewart DJ, Eberhardt WE, Ranade AA, Cohen G, Trigo JM, Sandler AB, et al. 2008. Randomized phase II study of vandetanib alone or with paclitaxel and carboplatin as first-line treatment for advanced non-small-cell lung cancer. J Clin Oncol 26: 5407-5415.

Hida K, Hida Y, Amin DN, Flint AF, Panigrahy D, Morton CC, Klagsbrun M. 2004. Tumor-associated endothelial cells with cytogenetic abnormalities. Cancer Res 64: 8249-8255.

Ho QT, Kuo CJ. 2007. Vascular endothelial growth factor: Biology and therapeutic applications. Int J Biochem Cell Biol 39: 1349-1357.

Hoff PM, Wolff RA, Bogaard K, Waldrum S, Abbruzzese JL. 2006. A Phase I study of escalating doses of the tyrosine kinase inhibitor semaxanib (SU5416) in combination with irinotecan in patients with advanced colorectal carcinoma. Jpn J Clin Oncol 36: 100-103.

Holden SN, Eckhardt SG, Basser R, de Boer R, Rischin D, Green M, Rosenthal MA, Wheeler C, Barge A, Hurwitz HI. 2005. Clinical evaluation of ZD6474, an orally active inhibitor of VEGF and EGF receptor signaling, in patients with solid, malignant tumors. Ann Oncol 16: 1391-1397.

Horti J, Widmark A, Stenzl A, Federico MH, Abratt RP, Sanders N, Pover GM, Bodrogi I. 2009. A randomized, double-blind, placebo-controlled phase II study of vandetanib plus docetaxel/prednisolone in patients with hormone-refractory prostate cancer. Cancer Biother Radiopharm 24: 175-180.

Hurwitz H, Fehrenbacher L, Novotny W, Cartwright T, Hainsworth J, Heim W, Berlin J, Baron A, Griffing S, Holmgren E, et al. 2004. Bevacizumab plus irinotecan, fluorouracil, and leucovorin for metastatic colorectal cancer. N Engl J Med 350: 2335-2342.

Hutson TE, Davis ID, Machiels JP, De Souza PL, Rottey S, Hong BF, Epstein RJ, Baker KL, McCann L, Crofts T, et al. 2010. Efficacy and safety of pazopanib in patients with metastatic renal cell carcinoma. J Clin Oncol 28: $475-480$.

Iwamoto FM, Lamborn KR, Robins HI, Mehta MP, Chang SM, Butowski NA, Deangelis LM, Abrey LE, Zhang WT, Prados MD, et al. 2010. Phase II trial of pazopanib (GW786034), an oral multi-targeted angiogenesis inhibitor, for adults with recurrent glioblastoma (North American Brain Tumor Consortium Study 06-02). Neuro Oncol 12: 855-861.

Izzedine $\mathrm{H}$, Rixe O, Billemont B, Baumelou A, Deray G. 2007. Angiogenesis inhibitor therapies: Focus on kidney toxicity and hypertension. Am J Kidney Dis 50: 203-218.

Izzedine H, Ederhy S, Goldwasser F, Soria JC, Milano G, Cohen A, Khayat D, Spano JP. 2009. Management of hypertension in angiogenesis inhibitor-treated patients. Ann Oncol 20: 807-815.

Jain RK, Duda DG, Clark JW, Loeffler JS. 2006. Lessons from phase III clinical trials on anti-VEGF therapy for cancer. Nat Clin Pract Oncol 3: 24-40.

Jayson GC, Mulatero C, Ranson M, Zweit J, Jackson A, Broughton L, Wagstaff J, Hakansson L, Groenewegen G, Lawrance J, et al. 2005. Phase I investigation of recombinant anti-human vascular endothelial growth factor antibody in patients with advanced cancer. Eur J Cancer 41: $555-563$.

Josson S, Matsuoka Y, Chung LW, Zhau HE, Wang R. 2010. Tumor-stroma co-evolution in prostate cancer progression and metastasis. Semin Cell Dev Biol 21: 26-32.

Kaiser PK, Blodi BA, Shapiro H, Acharya NR. 2007a. Angiographic and optical coherence tomographic results of the MARINA study of ranibizumab in neovascular age-related macular degeneration. Ophthalmology 114: $1868-1875$.

Kaiser PK, Brown DM, Zhang K, Hudson HL, Holz FG, Shapiro H, Schneider S, Acharya NR. 2007b. Ranibizumab for predominantly classic neovascular age-related macular degeneration: subgroup analysis of first-year ANCHOR results. Am J Ophthalmol 144: 850-857.

Karcher S, Steiner HH, Ahmadi R, Zoubaa S, Vasvari G, Bauer H, Unterberg A, Herold-Mende C. 2006. Different angiogenic phenotypes in primary and secondary glioblastomas. Int J Cancer 118: 2182-2189.

Kassmeyer S, Plendl J, Custodis P, Bahramsoltani M. 2009. New insights in vascular development: Vasculogenesis and endothelial progenitor cells. Anat Histol Embryol 38: $1-11$.

Kessler T, Bayer M, Schwoppe C, Liersch R, Mesters RM, Berdel WE. 2010. Compounds in clinical Phase III and beyond. Recent Results Cancer Res 180: 137-163.

Kieran MW, Supko JG, Wallace D, Fruscio R, Poussaint TY, Phillips P, Pollack I, Packer R, Boyett JM, Blaney S, et al. 2009. Phase I study of SU5416, a small molecule inhibitor 
M.W. Kieran et al.

of the vascular endothelial growth factor receptor (VEGFR) in refractory pediatric central nervous system tumors. Pediatr Blood Cancer 52: 169-176.

Kindler HL, Friberg G, Singh DA, Locker G, Nattam S, Kozloff M, Taber DA, Karrison T, Dachman A, Stadler WM, et al. 2005. Phase II trial of bevacizumab plus gemcitabine in patients with advanced pancreatic cancer. J Clin Oncol 23: 8033-8040.

Kitamura R, Asanoma H, Nagayama S, Otagiri M. 2008. Identification of human liver cytochrome P450 isoforms involved in autoinduced metabolism of the antiangiogenic agent $(Z)-5$-[(1,2-dihydro-2-oxo-3H-indol-3-ylidene)methyl]-2,4-dimethyl-1H-pyrro le-3-propanoic acid (TSU-68). Drug Metab Dispos 36: 1003-1009.

Kiura K, Nakagawa K, Shinkai T, Eguchi K, Ohe Y, Yamamoto N, Tsuboi M, Yokota S, Seto T, Jiang $\mathrm{H}$, et al. 2008. A randomized, double-blind, phase IIa dosefinding study of Vandetanib (ZD6474) in Japanese patients with non-small cell lung cancer. $J$ Thorac Oncol 3: $386-393$

Klagsbrun M, Takashima S, Mamluk R. 2002. The role of neuropilin in vascular and tumor biology. Adv Exp Med Biol 515: 33-48.

Konings IR, de Jonge MJ, Burger H, van der Gaast A, van Beijsterveldt LE, Winkler H, Verweij J, Yuan Z, Hellemans P, Eskens FA. 2010. Phase I and pharmacological study of the broad-spectrum tyrosine kinase inhibitor JNJ26483327 in patients with advanced solid tumours. Br J Cancer 103: 987-992.

Kontovinis LF, Papazisis KT, Touplikioti P, Andreadis C, Mouratidou D, Kortsaris AH. 2009. Sunitinib treatment for patients with clear-cell metastatic renal cell carcinoma: Clinical outcomes and plasma angiogenesis markers. BMC Cancer 9: 82. doi: 10.1186/14712407-9-82.

Kornblau SM, Womble M, Qiu YH, Jackson CE, Chen W, Konopleva M, Estey EH, Andreeff M. 2006. Simultaneous activation of multiple signal transduction pathways confers poor prognosis in acute myelogenous leukemia. Blood 108: 2358-2365.

Kourlas H, Abrams P. 2007. Ranibizumab for the treatment of neovascular age-related macular degeneration: a review. Clin Ther 29: 1850-1861.

Kovacs MJ, Reece DE, Marcellus D, Meyer RM, Mathews S, Dong RP, Eisenhauer E. 2006. A phase II study of ZD6474 (Zactima), a selective inhibitor of VEGFR and EGFR tyrosine kinase in patients with relapsed multiple myeloma-NCIC CTG IND.145. Invest New Drugs 24: 529-535.

Kowanetz M, Ferrara N. 2006. Vascular endothelial growth factor signaling pathways: Therapeutic perspective. Clin Cancer Res 12: 5018-5022.

Kuenen BC, Tabernero J, Baselga J, Cavalli F, Pfanner E, Conte PF, Seeber S, Madhusudan S, Deplanque G, Huisman $\mathrm{H}$, et al. 2003. Efficacy and toxicity of the angiogenesis inhibitor SU5416 as a single agent in patients with advanced renal cell carcinoma, melanoma, and soft tissue sarcoma. Clin Cancer Res 9: 1648-1655.

Kulke MH, Lenz HJ, Meropol NJ, Posey J, Ryan DP, Picus J, Bergsland E, Stuart K, Tye L, Huang X, et al. 2008. Activity of sunitinib in patients with advanced neuroendocrine tumors. J Clin Oncol 26: 3403-3410.
Kuo CJ, Farnebo F, Yu EY, Christofferson R, Swearingen RA, Carter R, von Recum HA, Yuan J, Kamihara J, Flynn E, et al. 2001. Comparative evaluation of the antitumor activity of antiangiogenic proteins delivered by gene transfer. Proc Natl Acad Sci 98: 4605-4610.

Lalwani GA, Rosenfeld PJ, Fung AE, Dubovy SR, Michels S, Feuer W, Davis JL, Flynn HW Jr, Esquiabro M. 2009. A variable-dosing regimen with intravitreal ranibizumab for neovascular age-related macular degeneration: Year 2 of the PrONTO Study. Am J Ophthalmol 148: 43-58.

Langenberg MH, Witteveen PO, Lankheet NA, Roodhart JM, Rosing H, van den Heuvel IJ, Beijnen JH, Voest EE. 2010. Phase 1 study of combination treatment with PTK 787/ZK 222584 and cetuximab for patients with advanced solid tumors: Safety, pharmacokinetics, pharmacodynamics analysis. Neoplasia 12: 206-213.

Lara PN, Quinn DI, Margolin K, Meyers FJ, Longmate J, Frankel P, Mack PC, Turrell C, Valk P, Rao J, et al. 2003. SU5416 plus interferon $\alpha$ in advanced renal cell carcinoma: A phase II California Cancer Consortium Study with biological and imaging correlates of angiogenesis inhibition. Clin Cancer Res 9: 4772-4781.

Lawler J, Detmar M. 2004. Tumor progression: The effects of thrombospondin-1 and -2. Int J Biochem Cell Biol 36: $1038-1045$.

Lee D. 2005. Phase II data with ZD6474, a small-molecule kinase inhibitor of epidermal growth factor receptor and vascular endothelial growth factor receptor, in previously treated advanced non-small-cell lung cancer. Clin Lung Cancer 7: 89-91.

Leek RD, Harris AL, Lewis CE. 1994. Cytokine networks in solid human tumors: Regulation of angiogenesis. J Leukoc Biol 56: 423-435.

Lindsay CR, MacPherson IR, Cassidy J. 2009. Current status of cediranib: The rapid development of a novel antiangiogenic therapy. Future Oncol 5: 421-432.

Lockhart AC, Rothenberg ML, Dupont J, Cooper W, Chevalier P, Sternas L, Buzenet G, Koehler E, Sosman JA Schwartz LH, et al. 2010. Phase I study of intravenous vascular endothelial growth factor trap, aflibercept, in patients with advanced solid tumors. J Clin Oncol 28: 207-214.

Lohela M, Bry M, Tammela T, Alitalo K. 2009. VEGFs and receptors involved in angiogenesis versus lymphangiogenesis. Curr Opin Cell Biol 21: 154-165.

Los M, Roodhart JM, Voest EE. 2007. Target practice: Lessons from phase III trials with bevacizumab and vatalanib in the treatment of advanced colorectal cancer. Oncologist 12: $443-450$.

Lubner SJ, Mahoney MR, Kolesar JL, Loconte NK, Kim GP, Pitot HC, Philip PA, Picus J, Yong WP, Horvath L, et al. 2010. Report of a multicenter phase II trial testing a combination of biweekly bevacizumab and daily erlotinib in patients with unresectable biliary cancer: A phase II Consortium study. J Clin Oncol 28: 3491-3497.

Mackay HJ, Tinker A, Winquist E, Thomas G, Swenerton K, Oza A, Sederias J, Ivy P, Eisenhauer EA. 2010. A phase II study of sunitinib in patients with locally advanced or metastatic cervical carcinoma: NCIC CTG Trial IND.184. Gynecol Oncol 116: 163-167.

Maeshima Y, Colorado PC, Torre A, Holthaus KA, Grunkemeyer JA, Ericksen MB, Hopfer H, Xiao Y, Stillman IE, 
Kalluri R. 2000. Distinct antitumor properties of a type IV collagen domain derived from basement membrane. J Biol Chem 275: 21340-21348.

Maione F, Molla F, Meda C, Latini R, Zentilin L, Giacca M, Seano G, Serini G, Bussolino F, Giraudo E. 2009. Semaphorin $3 \mathrm{~A}$ is an endogenous angiogenesis inhibitor that blocks tumor growth and normalizes tumor vasculature in transgenic mouse models. J Clin Invest 119: 3356-3372.

Matsumoto T, Claesson-Welsh L. 2001. VEGF receptor signal transduction. Sci STKE 2001: re21.

Miao HQ, Soker S, Feiner L, Alonso JL, Raper JA, Klagsbrun M. 1999. Neuropilin-1 mediates collapsin-1/semaphorin III inhibition of endothelial cell motility: Functional competition of collapsin-1 and vascular endothelial growth factor-165. J Cell Biol 146: 233-242.

Michael M, Gibbs P, Smith R, Godwood A, Oliver S, Tebbutt N. 2009. Open-label phase I trial of vandetanib in combination with mFOLFOX6 in patients with advanced colorectal cancer. Invest New Drugs 27: 253-261.

Miletic H, Niclou SP, Johansson M, Bjerkvig R. 2009. AntiVEGF therapies for malignant glioma: Treatment effects and escape mechanisms. Expert Opin Ther Targets 13: 455-468.

Miller KD, Chap LI, Holmes FA, Cobleigh MA, Marcom PK, Fehrenbacher L, Dickler M, Overmoyer BA, Reimann JD, Sing AP, et al. 2005a. Randomized phase III trial of capecitabine compared with bevacizumab plus capecitabine in patients with previously treated metastatic breast cancer. J Clin Oncol 23: 792-799.

Miller KD, Trigo JM, Wheeler C, Barge A, Rowbottom J, Sledge G, Baselga J. 2005b. A multicenter phase II trial of ZD6474, a vascular endothelial growth factor receptor- 2 and epidermal growth factor receptor tyrosine kinase inhibitor, in patients with previously treated metastatic breast cancer. Clin Cancer Res 11: 3369-3376.

Mita MM, Rowinsky EK, Forero L, Eckhart SG, Izbicka E, Weiss GR, Beeram M, Mita AC, de Bono JS, Tolcher AW, et al. 2007. A phase II, pharmacokinetic, and biologic study of semaxanib and thalidomide in patients with metastatic melanoma. Cancer Chemother Pharmacol 59: $165-174$.

Motzer RJ, Molina AM. 2009. Targeting renal cell carcinoma. J Clin Oncol 27: 3274-3276.

Motzer RJ, Michaelson MD, Redman BG, Hudes GR, Wilding G, Figlin RA, Ginsberg MS, Kim ST, Baum CM, DePrimo SE, et al. 2006. Activity of SU11248, a multitargeted inhibitor of vascular endothelial growth factor receptor and platelet-derived growth factor receptor, in patients with metastatic renal cell carcinoma. JClin Oncol 24: $16-24$.

Motzer RJ, Hutson TE, Tomczak P, Michaelson MD, Bukowski RM, Rixe O, Oudard S, Negrier S, Szczylik C, Kim ST, et al. 2007. Sunitinib versus interferon alfa in metastatic renal-cell carcinoma. N Engl J Med 356: 115-124.

Mross K, Drevs J, Muller M, Medinger M, Marme D, Hennig J, Morgan B, Lebwohl D, Masson E, Ho YY, et al. 2005. Phase I clinical and pharmacokinetic study of PTK/ZK, a multiple VEGF receptor inhibitor, in patients with liver metastases from solid tumours. Eur $J$ Cancer 41: 1291-1299.
Murakami M, Simons M. 2008. Fibroblast growth factor regulation of neovascularization. Curr Opin Hematol 15: $215-220$.

Natale RB, Bodkin D, Govindan R, Sleckman BG, Rizvi NA, Capo A, Germonpre P, Eberhardt WE, Stockman PK, Kennedy SJ, et al. 2009. Vandetanib versus gefitinib in patients with advanced non-small-cell lung cancer: Results from a two-part, double-blind, randomized phase ii study. J Clin Oncol 27: 2523-2529.

Nguyen QD, Shah SM, Browning DJ, Hudson H, Sonkin P, Hariprasad SM, Kaiser P, Slakter JS, Haller J, Do DV, et al. 2009. A phase I study of intravitreal vascular endothelial growth factor trap-eye in patients with neovascular age-related macular degeneration. Ophthalmology 116: 2141-2148.

Norden AD, Young GS, Setayesh K, Muzikansky A, Klufas R, Ross GL, Ciampa AS, Ebbeling LG, Levy B, Drappatz J, et al. 2008. Bevacizumab for recurrent malignant gliomas: Efficacy, toxicity, and patterns of recurrence. Neurology 70: 779-787.

O'Donnell A, Padhani A, Hayes C, Kakkar AJ, Leach M, Trigo JM, Scurr M, Raynaud F, Phillips S, Aherne W, et al. 2005. A Phase I study of the angiogenesis inhibitor SU5416 (semaxanib) in solid tumours, incorporating dynamic contrast MR pharmacodynamic end points. $\mathrm{Br}$ J Cancer 93: 876-883.

O'Farrell AM, Yuen HA, Smolich B, Hannah AL, Louie SG, Hong W, Stopeck AT, Silverman LR, Lancet JE, Karp JE, et al. 2004. Effects of SU5416, a small molecule tyrosine kinase receptor inhibitor, on FLT3 expression and phosphorylation in patients with refractory acute myeloid leukemia. Leuk Res 28: 679-689.

O'Reilly MS, Holmgren L, Shing Y, Chen C, Rosenthal RA, Moses M, Lane WS, Cao Y, Sage EH, Folkman J. 1994. Angiostatin: A novel angiogenesis inhibitor that mediates the suppression of metastases by a Lewis lung carcinoma [see comments]. Cell 79: 315-328.

O’Reilly MS, Boehm T, Shing Y, Fukai N, Vasios G, Lane WS, Flynn E, Birkhead JR, Olsen BR, Folkman J. 1997. Endostatin: An endogenous inhibitor of angiogenesis and tumor growth. Cell 88: 277-285.

Pande A, Lombardo J, Spangenthal E, Javle M. 2007. Hypertension secondary to anti-angiogenic therapy: Experience with bevacizumab. Anticancer Res 27: 3465-3470.

Patel PJ, Bunce C, Tufail A. 2008. A randomised, doublemasked phase III/IV study of the efficacy and safety of Avastin ${ }^{\circledR}$ (Bevacizumab) intravitreal injections compared to standard therapy in subjects with choroidal neovascularisation secondary to age-related macular degeneration: Clinical trial design. Trials 9: 56. doi: 10.1186/1745-6215-9-56.

Peterson AC, Swiger S, Stadler WM, Medved M, Karczmar G, Gajewski TF. 2004. Phase II study of the Flk-1 tyrosine kinase inhibitor SU5416 in advanced melanoma. Clin Cancer Res 10: 4048-4054.

Philip PA. 2008. Targeted therapies for pancreatic cancer. Gastrointest Cancer Res 2: S16-S19.

Ping G, Hui-Min W, Wei-Min W, Bao-Hui H. 2010. Sunitinib in pretreated advanced non-small-cell lung carcinoma: A primary result from Asian population. Med Oncol 28: 578-583. 
M.W. Kieran et al.

Polyzos A. 2008. Activity of SU11248, a multitargeted inhibitor of vascular endothelial growth factor receptor and platelet-derived growth factor receptor, in patients with metastatic renal cell carcinoma and various other solid tumors. J Steroid Biochem Mol Biol 108: 261-266.

Porta C, Paglino C, Imarisio I, Ferraris E. 2009. Sorafenib tosylate in advanced kidney cancer: Past, present and future. Anticancer Drugs 20: 409-415.

Ramjaun AR, Hodivala-Dilke K. 2009. The role of cell adhesion pathways in angiogenesis. Int J Biochem Cell Biol 41: $521-530$.

Ribatti D. 2009. Endogenous inhibitors of angiogenesis: A historical review. Leuk Res 33: 638-644.

Ribatti D, Nico B, Crivellato E. 2009. Morphological and molecular aspects of physiological vascular morphogenesis. Angiogenesis 12: 101-111.

Rini BI, Halabi S, Rosenberg JE, Stadler WM, Vaena DA, Ou SS, Archer L, Atkins JN, Picus J, Czaykowski P, et al. 2008. Bevacizumab plus interferon alfa compared with interferon alfa monotherapy in patients with metastatic renal cell carcinoma: CALGB 90206. J Clin Oncol 26: 5422-5428.

Rini BI, Wilding G, Hudes G, Stadler WM, Kim S, Tarazi J, Rosbrook B, Trask PC, Wood L, Dutcher JP. 2009. Phase II study of axitinib in sorafenib-refractory metastatic renal cell carcinoma. J Clin Oncol 27: 4462-4468.

Robinson BG, Paz-Ares L, Krebs A, Vasselli J, Haddad R. 2010a. Vandetanib $(100 \mathrm{mg})$ in patients with locally advanced or metastatic hereditary medullary thyroid cancer. J Clin Endocrinol Metab 95: 2664-2671.

Robinson ES, Matulonis UA, Ivy P, Berlin ST, Tyburski K, Penson RT, Humphreys BD. 2010b. Rapid development of hypertension and proteinuria with cediranib, an oral vascular endothelial growth factor receptor inhibitor. Clin J Am Soc Nephrol 5: 477-483.

Roboz GJ, Giles FJ, List AF, Cortes JE, Carlin R, Kowalski M, Bilic S, Masson E, Rosamilia M, Schuster MW, et al. 2006. Phase 1 study of PTK787/ZK 222584, a small molecule tyrosine kinase receptor inhibitor, for the treatment of acute myeloid leukemia and myelodysplastic syndrome. Leukemia 20: 952-957.

Rosen LS, Kurzrock R, Mulay M, Van Vugt A, Purdom M, Ng C, Silverman J, Koutsoukos A, Sun YN, Bass MB, et al. 2007. Safety, pharmacokinetics, and efficacy of AMG 706, an oral multikinase inhibitor, in patients with advanced solid tumors. J Clin Oncol 25: 2369-2376.

Rosenfeld PJ, Brown DM, Heier JS, Boyer DS, Kaiser PK, Chung CY, Kim RY. 2006. Ranibizumab for neovascular age-related macular degeneration. $N$ Engl J Med 355: 1419-1431.

Roskoski R Jr. 2008. VEGF receptor protein-tyrosine kinases: Structure and regulation. Biochem Biophys Res Commun 375: 287-291.

Rossi L, Zoratto F, Papa A, Iodice F, Minozzi M, Frati L, Tomao S. 2010. Current approach in the treatment of hepatocellular carcinoma. World J Gastrointest Oncol 2: 348-359.

Sadda SR, Stoller G, Boyer DS, Blodi BA, Shapiro H, Ianchulev T. 2010. Anatomical benefit from ranibizumab treatment of predominantly classic neovascular age-related macular degeneration in the 2-year anchor study. Retina 30: 1390-1399.
Samaras V, Piperi C, Levidou G, Zisakis A, Kavantzas N, Themistocleous MS, Boviatsis EI, Barbatis C, Lea RW, Kalofoutis A, Korkolopoulou P, et al. 2009. Analysis of interleukin (IL)-8 expression in human astrocytomas: Associations with IL-6, cyclooxygenase-2, vascular endothelial growth factor, and microvessel morphometry. Hum Immunol 70: 391-397.

Sandler A, Gray R, Perry MC, Brahmer J, Schiller JH, Dowlati A, Lilenbaum R, Johnson DH. 2006. Paclitaxelcarboplatin alone or with bevacizumab for non-smallcell lung cancer. N Engl J Med 355: 2542-2550.

Saunders MP, Wilson R, Peeters M, Smith R, Godwood A, Oliver S, Van Cutsem E. 2009. Vandetanib with FOLFIRI in patients with advanced colorectal adenocarcinoma: Results from an open-label, multicentre Phase I study. Cancer Chemother Pharmacol 64: 665-672.

Scott IU, Edwards AR, Beck RW, Bressler NM, Chan CK, Elman MJ, Friedman SM, Greven CM, Maturi RK, Pieramici DJ, et al. 2007. A phase II randomized clinical trial of intravitreal bevacizumab for diabetic macular edema. Ophthalmology 114: 1860-1867.

Semenza GL. 2007. Vasculogenesis, angiogenesis, and arteriogenesis: Mechanisms of blood vessel formation and remodeling. J Cell Biochem 102: 840-847.

Senger DR, Galli SJ, Dvorak AM, Perruzzi CA, Harvey VS, Dvorak HF. 1983. Tumor cells secrete a vascular permeability factor that promotes accumulation of ascites fluid. Science 219: 983-985.

Sharma S, Freeman B, Turner J, Symanowski J, Manno P, Berg W, Vogelzang N. 2009. A phase I trial of PTK787/ ZK222584 in combination with pemetrexed and cisplatin in patients with advanced solid tumors. Invest New Drugs 27: 63-65.

Shepard DR, Cooney MM, Elson P, Bukowski RM, Dreicer R, Rini BI, Garcia JA. 2010. A phase II study of tandutinib (MLN518), a selective inhibitor of type III tyrosine receptor kinases, in patients with metastatic renal cell carcinoma. Invest New Drugs doi: 10.1007/s10637-0109516-1.

Sherman SI, Wirth LJ, Droz JP, Hofmann M, Bastholt L, Martins RG, Licitra L, Eschenberg MJ, Sun YN, Juan T, et al. 2008. Motesanib diphosphate in progressive differentiated thyroid cancer. $N$ Engl J Med 359: 31-42.

Sloan B, Scheinfeld NS. 2008. Pazopanib, a VEGF receptor tyrosine kinase inhibitor for cancer therapy. Curr Opin Investig Drugs 9: 1324-1335.

Socinski MA, Novello S, Brahmer JR, Rosell R, Sanchez JM, Belani CP, Govindan R, Atkins JN, Gillenwater HH, Pallares C, et al. 2008. Multicenter, phase II trial of sunitinib in previously treated, advanced non-small-cell lung cancer. J Clin Oncol 26: 650-656.

Sozzani S, Rusnati M, Riboldi E, Mitola S, Presta M. 2007. Dendritic cell-endothelial cell cross-talk in angiogenesis. Trends Immunol 28: 385-392.

Stadler WM, Cao D, Vogelzang NJ, Ryan CW, Hoving K, Wright R, Karrison T, Vokes EE. 2004. A randomized Phase II trial of the antiangiogenic agent SU5416 in hormone-refractory prostate cancer. Clin Cancer Res 10: 3365-3370.

Summers J, Cohen MH, Keegan P, Pazdur R. 2010. FDA drug approval summary: Bevacizumab plus interferon for advanced renal cell carcinoma. Oncologist 15: 104-111. 
Tabernero J. 2007. The role of VEGF and EGFR inhibition: Implications for combining anti-VEGF and anti-EGFR agents. Mol Cancer Res 5: 203-220.

Tamura T, Minami H, Yamada Y, Yamamoto N, Shimoyama T, Murakami H, Horiike A, Fujisaka Y, Shinkai T, Tahara M, et al. 2006. A phase I dose-escalation study of ZD6474 in Japanese patients with solid, malignant tumors. J Thorac Oncol 1: 1002-1009.

Thomas AL, Morgan B, Horsfield MA, Higginson A, Kay A, Lee L, Masson E, Puccio-Pick M, Laurent D, Steward WP. 2005. Phase I study of the safety, tolerability, pharmacokinetics, and pharmacodynamics of PTK787/ZK 222584 administered twice daily in patients with advanced cancer. J Clin Oncol 23: 4162-4171.

Thompson EM, Dosa E, Kraemer DF, Neuwelt EA. 2010. Correlation of MRI sequences to assess progressive glioblastoma multiforme treated with bevacizumab. J Neurooncol 103: 353-360.

Timar J, Dome B. 2008. Antiangiogenic drugs and tyrosine kinases. Anticancer Agents Med Chem 8: 462-469.

Ton NC, Jayson GC. 2004. Resistance to anti-VEGF agents. Curr Pharm Des 10: 51-64.

van Cruijsen H, Voest EE, Punt CJ, Hoekman K, Witteveen PO, Meijerink MR, Puchalski TA, Robertson J, Saunders O, Jurgensmeier JM, et al. 2010. Phase I evaluation of cediranib, a selective VEGFR signalling inhibitor, in combination with gefitinib in patients with advanced tumours. Eur J Cancer 46: 901-911.

Van Meter ME, Kim ES. 2010. Bevacizumab: Current updates in treatment. Curr Opin Oncol 22: 586-591.

Varker KA, Biber JE, Kefauver C, Jensen R, Lehman A, Young $\mathrm{D}$, Wu H, Lesinski GB, Kendra K, Chen HX III, et al. 2007. A randomized phase 2 trial of bevacizumab with or without daily low-dose interferon alfa- $2 \mathrm{~b}$ in metastatic malignant melanoma. Ann Surg Oncol 14: 2367-2376.

Verhoeff JJ, van Tellingen O, Claes A, Stalpers LJ, van Linde ME, Richel DJ, Leenders WP, van Furth WR. 2009. Concerns about anti-angiogenic treatment in patients with
VEGF Pathway in Cancer and Disease

glioblastoma multiforme. BMC Cancer 9: 444. doi: 10.1186/1471-2407-9-444.

Veronese ML, Mosenkis A, Flaherty KT, Gallagher M, Stevenson JP, Townsend RR, O’Dwyer PJ. 2006. Mechanisms of hypertension associated with BAY 43-9006. J Clin Oncol 24: 1363-1369.

Voss MJ, Niggemann B, Zanker KS, Entschladen F. 2010. Tumour reactions to hypoxia. Curr Mol Med 10: 381-386.

Vredenburgh JJ, Desjardins A, Herndon JE II, Dowell JM, Reardon DA, Quinn JA, Rich JN, Sathornsumetee S, Gururangan S, Wagner M, et al. 2007. Phase II trial of bevacizumab and irinotecan in recurrent malignant glioma. Clin Cancer Res 13: 1253-1259.

Wary KK. 2004. Molecular targets for anti-angiogenic therapy. Curr Opin Mol Ther 6: 54-70.

Wells SA Jr, Gosnell JE, Gagel RF, Moley J, Pfister D, Sosa JA, Skinner M, Krebs A, Vasselli J, Schlumberger M. 2010 Vandetanib for the treatment of patients with locally advanced or metastatic hereditary medullary thyroid cancer. J Clin Oncol 28: 767-772.

Wen PY, Macdonald DR, Reardon DA, Cloughesy TF, Sorensen AG, Galanis E, Degroot J, Wick W, Gilbert MR, Lassman $A B$, et al. 2010. Updated response assessment criteria for high-grade gliomas: Response assessment in neuro-oncology working group. J Clin Oncol 28: 1963-1972.

Yan L, Anderson GM, DeWitte M, Nakada MT. 2006. Therapeutic potential of cytokine and chemokine antagonists in cancer therapy. Eur J Cancer 42: 793-802.

Yla-Herttuala S, Rissanen TT, Vajanto I, Hartikainen J. 2007. Vascular endothelial growth factors: Biology and current status of clinical applications in cardiovascular medicine. J Am Coll Cardiol 49: 1015-1026.

Zangari M, Anaissie E, Stopeck A, Morimoto A, Tan N, Lancet J, Cooper M, Hannah A, Garcia-Manero G, Faderl S, et al. 2004. Phase II study of SU5416, a small molecule vascular endothelial growth factor tyrosine kinase receptor inhibitor, in patients with refractory multiple myeloma. Clin Cancer Res 10: 88-95. 


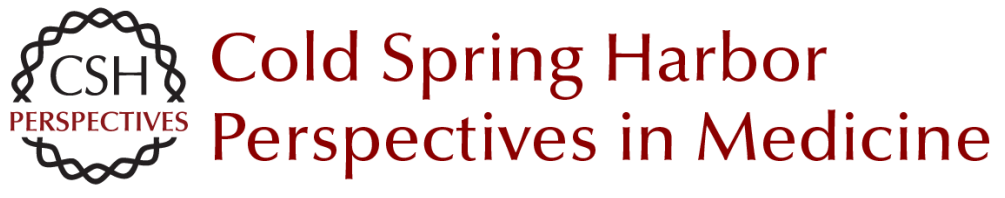

\title{
The VEGF Pathway in Cancer and Disease: Responses, Resistance, and the Path Forward
}

\author{
Mark W. Kieran, Raghu Kalluri and Yoon-Jae Cho
}

Cold Spring Harb Perspect Med 2012; doi: 10.1101/cshperspect.a006593 originally published online July 18,2012

\section{Subject Collection Angiogenesis}

Extracellular Matrix Regulation of Vascular Morphogenesis, Maturation, and Stabilization George E. Davis and Scott S. Kemp

Endothelial Cell-Pericyte Interactions in the

Pathogenesis of Cerebral Cavernous

Malformations (CCMs)

Wang Min and Jenny Huanjiao Zhou

Lymphatic Clearance and Pump Function Jerome W. Breslin

Platelets and (Lymph)angiogenesis Harvey G. Roweth and Elisabeth M. Battinelli

Modeling Brain Vasculature Immune Interactions In Vitro

Ruth Lyck, Hideaki Nishihara, Sidar Aydin, et al.

Human Endothelial Colony-Forming Cells Juan M. Melero-Martin

The Beauty and Complexity of Blood Vessel Patterning Victoria L. Bautch and Yoh-suke Mukouyama

Endothelialitis, Microischemia, and Intussusceptive Angiogenesis in COVID-19 Steven J. Mentzer, Maximilian Ackermann and Danny Jonigk
Regulation of the Blood-Brain Barrier in Health and Disease

Cara C. Rada, Kanako Yuki, Jie Ding, et al.

Targeting Angiogenesis via Resolution of Inflammation

Abigail G. Kelly and Dipak Panigrahy

Notch Signaling in the Vasculature: Angiogenesis and Angiocrine Functions

Sana S. Hasan and Andreas Fischer

Signal Transduction and Gene Regulation in the

Endothelium

Michel V. Levesque and Timothy Hla

Buttons and Zippers: Endothelial Junctions in

Lymphatic Vessels

Peter Baluk and Donald M. McDonald

Endothelial Cell Fate Determination: A Top Notch Job in Vascular Decision-Making

L.A. Naiche, Stephanie R. Villa and Jan K. Kitajewski

Leukocyte Trafficking in Lymphatic Vessels Aline Bauer, Hazal Tatliadim and Cornelia Halin

Lymphatic Tissue and Organ Engineering for In Vitro Modeling and In Vivo Regeneration Anna M. Kolarzyk, Gigi Wong and Esak Lee

For additional articles in this collection, see http://perspectivesinmedicine.cshlp.org/cgi/collection/ 